\title{
Financial Entrepreneurial Ecosystems: An Analysis of Urban and Rural Regions of Norway
}

\author{
Tore Frimanslund $^{1}$ (D)
}

Received: 3 August 2021 / Accepted: 24 January 2022 / Published online: 16 February 2022

(c) The Author(s) 2022

\begin{abstract}
Based on the entrepreneurial ecosystem (EE) perspective, this paper examines the role of finance and interrelated valueadding activities in ecosystems. The study employs a multiple-case design and interviews with 11 rural and urban innovative start-ups and stakeholders in the Norwegian market for entrepreneurial financing. The analysis disentangles the term recycling of entrepreneurial resources in ecosystems, explained here as a self-enhancing cycle of finance under certain conditions that allows enhancement of the ecosystem and members. The aim is to explain these mechanisms in business-level ecosystems, why they are important, and how they are new to entrepreneurship theories. The study argues that the robustness of ecosystems is characterised by the extent of such activities and how they affect entrepreneurial and regional growth. Bottom-up ecosystems can be spatially scattered and enable start-ups in disadvantageous localities to harvest critical resources from more advantageous places. This study provides a theoretical extension of EEs.
\end{abstract}

Keywords Financial entrepreneurial ecosystem $\cdot$ Access to finance $\cdot$ Entrepreneurial recycling $\cdot$ Multiple-case design

\section{Introduction}

In their study about entrepreneurial ecosystems, Spigel and Harrison (2018) state that

It is important to understand how resources flow within the ecosystem, how they are produced by internal mechanisms such as recycling of both successful and unsuccessful ventures, and how they can also be attracted into the ecosystem by the global pipelines entrepreneurs create.

This study aims to see these mechanisms through the lens of finance. This issue has received little attention in the current literature (see e.g. Lerner et al., 2018; Radinger-Peer et al., 2018; Wurth et al., 2021). Due to its high relevance for firm-level competitiveness (Momaya, 2019) and policy, the study attempts to explore the financial configurations and break down the popular concept of recycling of resources in entrepreneurial ecosystems. Resources in this context

Tore Frimanslund

tore.frimanslund@hvl.no

1 Department of Business and Administration, Western Norway University for Applied Sciences, Røyrgata 6, 6856 Sogndal, Norway may be financial capital for entrepreneurs and interrelated value-adding activities. Notable examples are an investor's or serial entrepreneur's growth and commercialisation competencies, skilled workers and mentors, governance and network access (Spigel \& Harrison, 2018; Wurth et al., 2021). These resources are of particular value for high-growthoriented, capital-intensive and innovative start-ups, which depend on sufficient availability to grow. The rationale for the study is the presumption of the recycled entrepreneurial resources-that the quality of financial ecosystems is associated with the degree to which such resources are re-invested by eligible members of the system (i.e. previously successful or even unsuccessful entrepreneurs).

The EE framework may be defined as 'a set of interdependent actors and factors coordinated in such a way that they enable productive entrepreneurship within a particular territory' (Stam \& Spigel, 2016). However, it is not clear how an ecosystem can be improved, including with what goals and to what elements (Acs et al., 2017). The inclusion of both actors and factors leaves this definition open to several ways of interpretation. It may be measured by the six domains of Isenberg's model (Isenberg, 2010, 2011; Liguori et al., 2019; Stam, 2018; Vedula \& Kim, 2019) or it may follow the logic of the process theory of Spigel and Harrison (2018). Whereas Isenberg focuses on 
six interrelating factors that promote regional entrepreneurship, Spigel and Harrison seem to focus on interrelating actors in a business-level ecosystem and less on the factors that promote it.

Using the same terminology for such different approaches has implications for what we try to examine and may be a reason why the EE literature is so frequently considered fuzzy. When functional ecosystems in regional development are viewed as a set of factors such as culture, infrastructure, markets, finance, human capital and support (Isenberg, 2011), the debate takes place at a scale relevant to economic geographers. By contrast, Spigel and Harrison (2018) process theory looks at how the interrelation of individual actors makes up an ecosystem, which draws attention from research fields such as strategic management (Acs et al., 2017). This study thus positions itself in the strategic management literature and tries to contribute new insights on the internal processes of functioning ecosystems from the perspective of financial actors. At the same time, it builds on literature in regional development and presents arguments for why understanding such strategic business ecosystems is important for regional growth, where entrepreneurship is defined as a main outcome (Stam, 2018).

The interview guide and data collection of this study were influenced by various theories for exploring and explaining how the mentioned processes play out. The inquiry required assessing two theoretical lines of thought. In addition to the process theory of EE, the behaviour of entrepreneurs and stakeholders can, to a large extent, be described by the theoretical fundament of entrepreneurial and corporate finance. As the body of corporate finance literature is traditionally accustomed to highlighting informational issues, such as the relationship between a risk-bearing investor and a firmforming agent, another contribution to the literature is to focus on how ecosystem 'recycling' may have the ability to ameliorate such relations in ways novel to the fast-growing EE literature. The concept implies a self-enhancing cycle of finance under certain conditions that allows enhancement (such as employing an ecosystem investor's track records and legitimacy in further finance and resource acquisitions).

Against this background, the research questions guiding this study are as follows: what are the main determinants of financial access for start-ups, and how are finance and value-adding activities acquired and distributed in entrepreneurial ecosystems? The study employs a multiple-case study of rural and urban Norwegian entrepreneurs and actors involved in entrepreneurial financing. This study considers rural and urban contexts in which EEs emerge through the lens of finance and examines the causal mechanisms of ecosystem finance by exploring its determinants, sources and outcomes in the Norwegian context. The multiple-case method based on the tradition of (Eisenhardt, 1989b) partially grounds the inductive process in a way that focuses on the informants' own perspectives while allowing the analysis to be illuminated by theoretical insights.

Following the appropriate tradition, the main goal is for the study to culminate in a theoretical framework that illustrates what it describes as the recycling mechanisms of entrepreneurial finance and related value-added activities in ecosystems. The model, which is labelled the Financial Entrepreneurial Ecosystem framework (FEE), explains how critical resources are acquired and re-invested. As different EE frameworks already exist (Stam, 2015) this label is chosen to outline the model's focus on the financial dynamics of ecosystems.

This study informs and advice policymakers to stimulate loop effects of proximally re-invested acquired capital and related value added. Based on the informants' inputs, the proposed framework is considered a viable path towards unleashing even more of the potential in both established start-up communities as well as deprived or rural areas where Isenberg's six components are not necessarily present. According to Malecki (2018), successful ecosystems may depend on a critical mass of new firms. This study will add, however, that a critical necessity is some sort of entrepreneurial or industrial success to build on. A characteristic of this framework is, therefore, its multi-scalar applicability, as the proposed framework's characteristics are shared between small and rural business networks as well as national financial systems.

Despite the contextual anchoring in Norway, financeintensive, innovative and technological firms seem to follow international trends, which increase the transferability of the findings to other contexts. The rationale for this study was best phrased by an informant who stated that a strategic policy of fostering entrepreneurship that does not focus on a functioning and sustainable feedback cycle of know-how, network access and capital reinvestments is unlikely to succeed. The vision, therefore, is to continue the process of chiselling out a clear-cut theory on a set of interrelations of firm entrepreneurial growth centred on financial access.

"Literature Review" presents a brief theoretical background on ecosystems, while "Materials and Methods" elaborates the steps taken to ensure methodological rigour and logic from data to theory. The findings and discussion sections are presented in "Findings" and "Discussion", respectively, and the study culminates in a conceptual model illustrating the main determinants of capital access, performance measures and ecosystem recycling. 


\section{Literature Review}

\section{The Emergence of EE}

Marshall (1919) referred to the 'Industrial atmosphere', where he described how knowledge is shared between actors and where trust reduces the transaction costs between firms (Asheim, 1996). This thought still resonates in today's ecosystem perspective, and since then, system theories have aimed to explain innovation and development. Notable examples are regional innovation systems (Cooke et al., 1997), industrial clusters (Porter, 1998), and the triple helix framework (Etzkowitz, 2008). Whether the output is knowledge sharing or innovation rates, such theories are justified by the same powerful rationale, and more or less designed to address facets of the same phenomenon-aggregated wealth creation.

As most of these approaches have to various extents overlooked the role of the entrepreneur, Van de Ven (1993) highlighted the need for an entrepreneurial infrastructure, and Spilling (1996) introduced the concept of the entrepreneurial system to illustrate the entrepreneurial performance of regions and localities. As he argues, research on entrepreneurship had until that point tended to focus on the individual firm level. Zacharakis et al. (2003) took a step further and looked at how a recycling ecosystem in Silicon Valley was supported by three interrelating pillars, one of which was venture capital. Their conceptual model came close to the current definition of EE, as they state that 'different geographic regions possess different ecosystem qualities that benefit some Internet sectors and not others'.

According to Theodoraki and Catanzaro (2021), the current literature on EEs can be categorised using five axes, namely (1) structural, (2) systemic, (3) evolutionary, (4) spatial and (5) international. Financial access and "smart capital" is considered one of the most crucial building blocks of entrepreneurship (Cassar, 2004; Politis, 2008), but the literature has yet to produce knowledge on the financial dynamics in entrepreneurial ecosystems. This study would therefore position itself as relevant to more than one category.

The literature on EE, both academic and popular, reveals that the concept is regarded as a highly promising interaction of interrelated elements. A nascent part of the literature aims to create measurable constructs on the regional level (see e.g. Liguori et al., 2019; Stam, 2018; Vedula \& Kim, 2019), but recurring patterns of inter-firm dynamics in ecosystems seem to remain absent. An assumption of the EE framework is systemic self-sustainability, a concept inspired by natural ecology (Acs et al., 2017), and the presence of feedback loops seem to be characteristic of a system that successfully fosters new ventures over time (Spigel \& Harrison, 2018). Spigel and Harrison's process theory is regarded as the closest relative to this study's conceptual output. However, although they capture the internal dynamics of ecosystem in a fascinating way that resonates very much with this study's views, they do not explain how financial ties develop between the ecosystem's actors.

Strong ecosystems may facilitate self-reinforcing access to smart capital and value-added activities (e.g. governance, competency and network access). Furthermore, undiscovered but assumable causal benefits of ecosystems are the abilities to reduce asymmetric information between firms and stakeholders. This implies that ecosystem configurations may enhance start-up or investor legitimacy (see e.g. Alperovych et al., 2015; Hsu, 2004) and provide collateral for further external capital acquisition. The economic and incentive-based interrelations and bindings between actors may, therefore, increase the availability of resources and knowledge. They may also create a certain balance to the business ecosystem in the way that member actors reinforce each other from the 'bottom-up', which would protect a traditional business cluster from fragmentation. Therefore, there may be multiplication effects of a functioning ecosystem yet to be examined.

\section{The Role of Proximity}

A relevant concept worthy of mention is proximity. Boschma (2005) state that geographical proximity cannot be assessed in isolation and that there are other dimensions of proximity (cognitive, organisational, social, and institutional) that may help us understand how ecosystems may emerge even in deprived areas. Recent evidence has even shed doubt on the role of cities in fostering innovation (Fitjar \& RodríguezPose, 2019), suggesting that there are other factors in play. In its purest form, agglomeration and spillover theory favour dense cities, but against the background of proximity, interregional and international collaboration seem to play a role in innovation in peripheral regions, challenging traditional assumptions of the role of cities. To facilitate recycling of resources, overcoming proximal hindrances to resource acquisition is assumed to be critical.

Proximity also presents implications for the cases. As regional developers tend to examine ecosystems as, for instance, provincial, national, nested or polycentric configurations (Ostrom, 2010; Stam, 2018), the entrepreneurial and corporate finance literature suggests focusing on a set of relational mechanisms (e.g. asymmetric information between the investor and investee) and disregard geographical boundaries. Therefore, as EE lacks a strong theoretical foundation (Spigel \& Harrison, 2018), this study aims to develop EE's theoretical link to the realms of management and corporate finance. 


\section{Ecosystem Finance}

As with entrepreneurs, financial organisations tend to be overlooked in regional innovation systems (Gjelsvik \& Trippl, 2018). Moreover, although policies seem to add density to clusters, the added value of such policies and the role of financial actors in clusters are uncertain (Nathan, 2019). Research on this topic tends to focus on how venture capital, as an alleged driver of regional change, is spatially distributed (Sorenson \& Stuart, 2001). Venture capital, however, is one particular source of finance that is most commonly available and mature in financial ecosystems in equity-based economies (Bornefalk, 2014) and therefore is not as applicable to all contexts. Finance is, in any case, a critical component of entrepreneurship (Cassar, 2004), and the body of literature on entrepreneurial finance has gradually increased since the 1990s (Denis, 2004; Landström, 2017, p. 17).

Within the realm of entrepreneurial finance, wellknown and robust management concepts such as agency issues and informational asymmetry (Eisenhardt, 1989a; Jensen \& Meckling, 1976) provide tools to understand the challenges of acquiring external finance (Ang, 1992; Denis, 2004), with subsequent relevance to financial ecosystems. Such theories are closely related to signalling theory (Spence, 1978), which focuses on overcoming the informational gap. Therefore, a proposition for this study is that an individual start-up will encounter a certain level of difficulties addressing the informational asymmetry determined by the lack of track record and legitimacy. In a developed ecosystem, however, interrelations with other entrepreneurs might provide security and collateral and thus dampen this asymmetry. Such mechanisms will also be appropriately explained by signalling theory. In the final model, all of these theories help shed light on the informant's patterns of accounts as a theoretical backdrop due to their explanatory powers for the acquisition behaviour of finance and related resources.

Although these relevant theories are considered fundamental for managerial and entrepreneurial behaviour, a few methodological issues still exist. Primarily, these theories rest on assumptions of rational behaviour and perfect markets (Landström, 2004, 2017, p. 8). Such characteristics may apply to large and mature firms with records of accomplishment and tangibles but not necessarily to new firms with nothing but promises. Due to the non-financial incentives of the founders, the lack of track records for the team and operations, intangibility and a high degree of both technology and market uncertainty, research on SMEs and, in particular, high-tech start-ups could benefit from a different treatment and even epistemological approaches then mature firms.

\section{Materials and Methods}

As explained above, individual finance acquisition behaviour can be described theoretically, but there is no appropriate framework that explains the financial dynamics in ecosystems. This means that the method adopted here is to elaborate a theory while incorporating relevant theoretical knowledge. The study employs an inductive embedded multiple-case study design, which is a useful tool for theory building regarding underdeveloped constructs or processes (Eisenhardt, 1989b; Ozcan \& Eisenhardt, 2009; Yin, 2013, p. 187), such as the internal dynamics of ecosystems (Spigel, 2017).

As mentioned above, the financial interrelations of ecosystems are yet to be examined. The method is therefore not to 'go full grounded' but to develop a unique theory against the background of the well-tested informational and principal/agent relations of finance and the process theory of Spigel and Harrison (2018). Further supporting the choice of methodology, the epistemological nature of the study stance does not necessarily involve the same interpretative view suggested by a grounded theory (Gehman et al., 2018). In a digital and globalised world, modern business ecosystem mechanisms may be increasingly transferrable to other contexts. This means that it should be possible to extract and conceptualise the essential interrelations so the different ecosystems will only vary in their contextual variances of the model's components. Although some researchers advise against the use of quantitative logics such as replication to qualitative studies (Pratt et al., 2019), the proposed theory will be transferable and replicable according to the multiple-case study logic that underlies the research tradition of (Eisenhardt, 1989b).

Based on the outline in "Literature Review", the Norwegian financial ecosystem for entrepreneurial finance is chosen as the study's case. To add a robustness of complementary views on the same phenomenon, the case is viewed in two different geographic contexts. The contextual difference is for research design only, as the actors within might operate across regions. Figure 1 illustrates the embedded research design based on (Yin, 2013, p. 50) and the selection of actors operating within the financial ecosystem (investors, investees, policymakers and support agencies). A purposive and theoretical sampling (Eisenhardt, 1989b) was conducted to include a wide and representative variety of actors in the market for entrepreneurial finance who either supply, demand or facilitate/mediate entrepreneurial finance. As such, the pitfall of drawing inferences from non-representative processes, events and activities was avoided (Miles \& Huberman, 1994, p. 264). 
Fig. 1 Embedded multiple-case study research design (Yin, 2013)
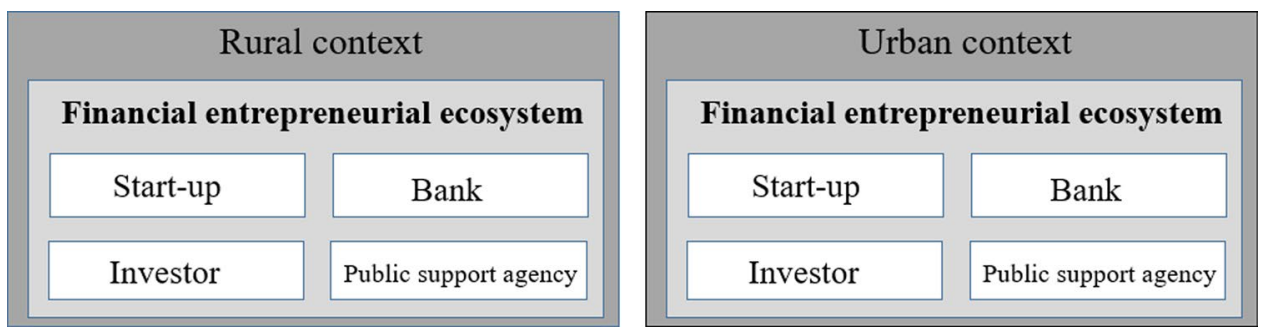

Table 1 sums up the 10 selected cases and 11 informants located in the Norwegian capital of Oslo and in the rural region of Sogn \& Fjordane in Vestland County.

\section{Study Context and Background}

Norway and its neighbouring Scandinavian countries are traditionally characterised as subsidy-based economies (Bornefalk, 2014; Landström, 2017, p. 26). The shift of private wealth towards entrepreneurship has received increased attention as economic forecasts predict that the Norwegian economy must reduce its reliance on the dominant offshore sector. Financial availability has been proposed as a primary obstacle to achieving this goal (Kapitaltilgangsutvalget, 2018). The report by Kapitaltilgangsutvalget (2018) states there is no deficit of private equity that may be allocated towards new technologies and ventures, although such shifts are hindered by several other factors relevant to this study's aim. Recent studies (currently unpublished) have supported and justified governmental strategies and indicate that new ventures created two-thirds of all new jobs between 2003 and 2014 in Norway. Of these, one-third came from technological and scalable SMEs (Reve, 2017).

\section{Data Collection, Processing and Analysis}

The semi-structured interview guide was based on the initial research questions. Open-ended questions were used to enable the researchers to empathise and elaborate their own experiences and dynamics (Kvale, 2008, p. 12). The interviewees were informed that their names would be withdrawn from all written material, although their firms and types would be published. That did not seem to be problematic as the topics did not include personal or controversial characteristics. It should be noted that the interviewees, despite their positions, showed very little ambiguity in their answers, thus adding consistency to the model.

Because related theory was considered to be valuable, the process from data to theoretical inference was guided by the traditions of Yin $(2013$, p. 60) and Eisenhardt (1989b) and by the operational recommendations of Miles and Huberman (1994). After skimming the interviews to obtain an overview, individual case reports were written. These reports were sent to the interviewees to confirm the statements and interpretations. These reports were purely descriptive and highlighted quotes and measures that were interesting from the viewpoint of this study. Following the case reports, a cross-case analysis was conducted to find and systemise common themes and patterns. During this phase, the literature from "Literature Review" was referred to in order to identify support, conflicts or nuances compared with the selected theoretical backgrounds and the conceptual model. Simultaneous with these reports, findings and opinions were coded and listed in an Excel sheet. After the codes were analysed and

Table 1 Interview report table

\begin{tabular}{lllll}
\hline$\#$ & Organisation & Stakeholder function & Location & Duration (h) \\
\hline 1. & Domos & High-tech start-up & Urban-Oslo & 1 \\
2. & Innovation Norway \#1 & Public support agency & Urban-Oslo & 1.5 \\
3. & Innovation Norway \#2 & Public support agency & Urban-Oslo & 1.5 \\
4. & DNB & Bank & Urban-Oslo & 1 \\
5. & Abelia/FIN & Public support agency & Urban-Oslo & 1 \\
6. & Argentum & Investor & Urban-Oslo & 1 \\
7. & Startuplab & Hub/investor & Urban-Oslo & 1 \\
8. & Innovation Norway & Public support agency & Rural-Sogndal & 1.5 \\
9. & nLink & High-tech start-up & Rural-Sogndal & 1.5 \\
10. & Sparebanken S\&F & Bank & Rural-Førde & 1.5 \\
11. & Fjord Invest & Investor & Rural-Førde & 1
\end{tabular}


developed into measures and aggregated constructs, several insights were gained at the analytical level that might have been overlooked during the interviews and individual case write-ups.

The data are not longitudinal and therefore do not allow an examination of how processes play out, but recurring topics were the importance of feedback loops and interrelations. Terms like 'entrepreneurial ecosystem', 'financial ecosystem', and 'pockets of innovation' centred around the relationship between the entrepreneur and private financier

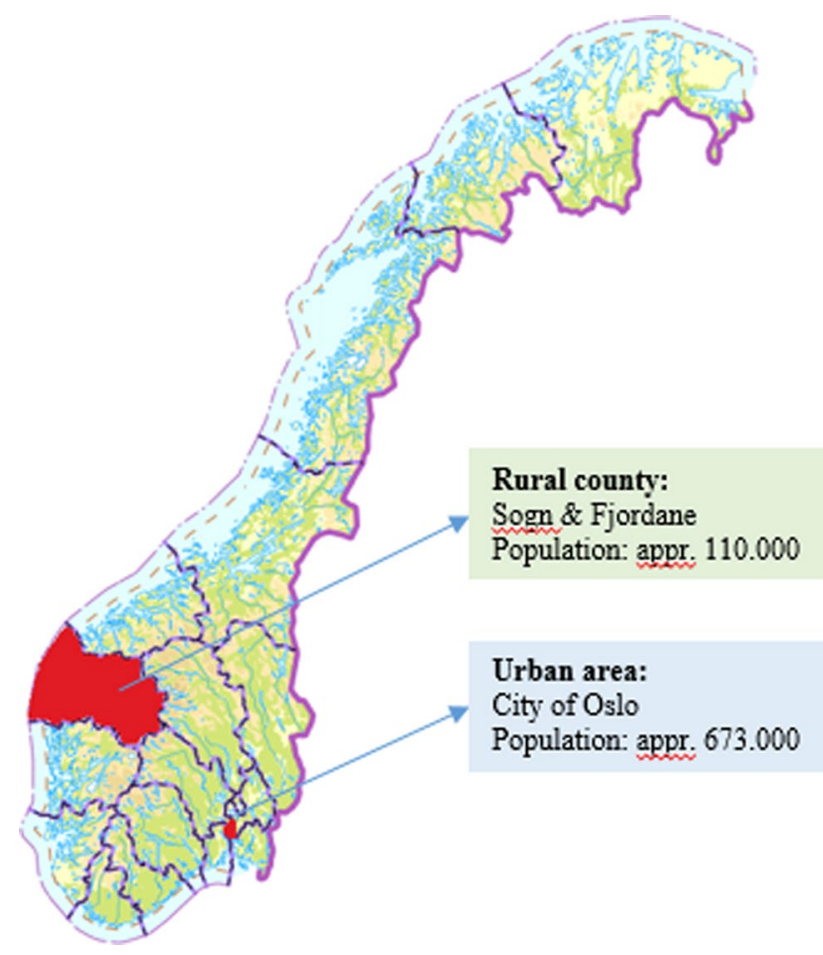

Fig. 2 The case study regions of Norway ( source: norgeskart.no) were constantly mentioned. Through the research process, the interview data was compressed and reduced into a short list of manageable and potentially measurable constructs.

\section{Findings}

The following sections present an overview of the financial sources and common determinants that emerged from the data. The determinants and ecosystem mechanisms are then positioned in relation to each other based on the data in the designated Fig. 2. Detailed tables of the representative data can be found in Appendix with captions Table A1-A6 in supplementary file.

\section{Entrepreneurial Growth Finance}

In the literature, there is little dispute about the definitions of financial sources, and the informants were consistent in their use of common terminology. 'Private capital' mostly refers to business angels, industrial investors, venture capital and private equity funds and includes institutional funds. Some of these sources may trigger or be triggered by governmental matching capital. The informants were expected to be more aware of bootstrapping (own funding) or crowdfunding, but such topics were mostly treated as too nascent or peripheral. Finance for the early start-up phase did not attract much attention, as Norwegian governmental support agencies seem to fill this gap to a satisfactory extent. Based on the interviews, a main distinction should be made between short-term and igniting start-up funding and longterm growth funding. The informants seem to be more concerned about the latter, where often personal risk exposure and therefore incentives to engage in risk dampening-related value-adding activities play an important role. Figure 3
Fig. 3 Codes and measures of financial source

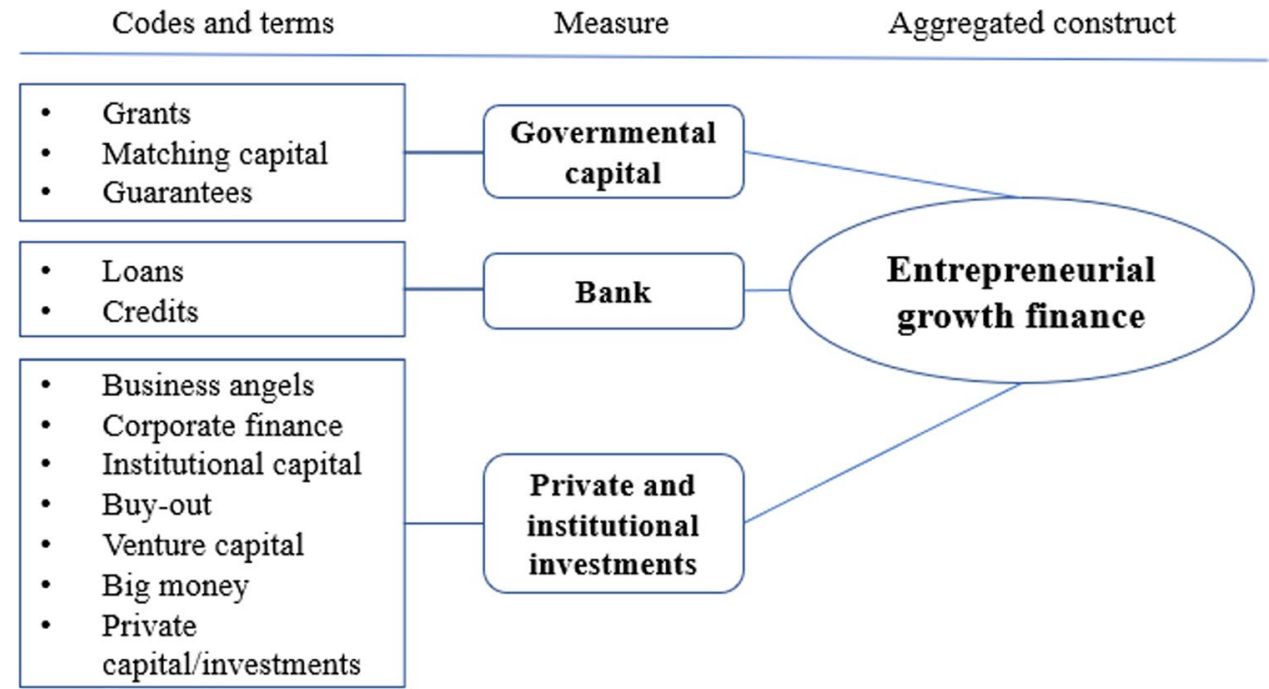


provides a brief overview of the financial terms commonly used by the informants.

Compared with the literature, this list is not extensive. The lack of focus on financing methods based on crowdfunding may indicate underdeveloped regulations and markets, and the lack of focus on bootstrapping may be due to efficient and widely available grant schemes. Such measures will differ depending on context and economy type. In any case, governmental matching capital is said to unlock private investments. Other studies have found such matching capital to dampen the risk for private engagements (Cumming et al., 2014; Guerini \& Quas, 2016; Leleux \& Surlemont, 2003). For private investments, the pecking order framework predicts that equity stakes are the least preferred option of capitalisation, as such money is traded for corporate control (Myers, 1984). These predictions are not necessarily supported when examined in light of the modern-day situation of high-tech scale-ups. Most notably, such scale-ups realise that they do not qualify for bank loans and may prefer external smart capital from 'day 1'. In fact, access to initial value-added activities through investments in exchange for shares is seen as a main motivation to joining an ecosystem in the first place. Despite the last selected quote in Table A1 in supplementary file, bank financing is found to be the key finance supplier for SMEs (Kerr \& Nanda, 2015). Representative data for the terms in quotes are found in the following sections.

When it comes to financial sources, a context-dependent difference (between economies) is the use of the terms venture capital (VC) and private equity (PE). Venture capital is often referred to as 'equity to ventures' in general. In the practical world, $\mathrm{VC}$ refers to specific funds aimed at the early phase and can best be described as a unique business model. PE was referred to by the participants in this study as private equity funds traditionally intended for more mature sectors. The informants argued, however, supported by other studies (see e.g. Gjelsvik \& Trippl, 2018), that the focus of $\mathrm{VC}$ investors is shifting towards less risky mature entrepreneurial industries, while some actors of PE are engaging in risky unproven high-tech concepts. This makes the borderline diffuse, especially from the investee's point of view. The representative data can be found in Table A1 in supplementary file.

\section{The Role of Value-Adding Activities}

The most frequently mentioned determinants for the Norwegian context are issues concerning network access, particularly for rural initiatives. Access to critical growth and commercialisation competencies is considered to be proximally less available and is reportedly hindered by cultural issues and regional preferences concerning ownership. One informant referred to this barrier as a type of 'regional protectionism' that even existed within the office walls of support agencies. Furthermore, access to these resources is limited by the degree of regional business sector homogeneity. This makes local money less available for firms developing unrelated technologies because cross-sector investment requires funders to engage in something unfamiliar. The issue was believed to be more critical in rural than in urban settings because business sector diversity increases with agglomeration. Elaborating on cultural issues, a tendency to want to keep ownership local or in the hands of known persons was noted. Non-regional buy-outs and acquisitions were often seen as a threat to local businesses, as they would face the risk of having to move out of the region and thus increase the risk of loss of critical jobs. Especially in rural contexts, such as the Sogn \& Fjordane county region, local businesses are marginally more important to the regional economy than they are in urban contexts. On the other hand, the informants mentioned that non-regional investors were of vital importance due to the added value they brought in terms of growth and commercialisation competencies and access to networks. Therefore, a conflict exists between local stakeholder preferences and considerations for optimal firm growth. The rural investor informant mentioned that even though the rural investee would end up being sold and moved, the entrepreneurial knowledge, money and resources in the region would increase, which could spur new firms (Fig. 4).

There is an abundance of data concerning value-adding activities, so the focus is on presenting the most representative quotes. These can be found in Table A 2 in supplementary file.

These findings are supported by decades of research on topics such as networks and structural holes (Burt, 2004). There is now little dispute over the agglomeration effects that benefit access to competence, capital and networks in rural areas. However, as pointed out by a few of the informants and similar studies, well-connected rural entrepreneurs can overcome this gap (Bastesen \& Vatne, 2014). Here, the role of value-adding activities is not seen as static but as a dynamic and continuous cyclical process of reinvesting acquired value and competencies. As argued in "Literature Review", there does not seem to be a theoretical tool to explain these dynamics, expect to a certain degree by the business ecosystem model proposed by Spigel and Harrison (2018). In the literature, such dynamics are further supported by the notion that value-adding activities act as both determinants of capital access and mediators of the relationship between sources of capital and performance measures (see e.g. Peneder, 2010; Politis, 2008). 
- Network access

- Demand for meeting places and arenas between start-up and investor

- Demand for cooperation with industrial actors

- Support agencies facilitating or mediating network access

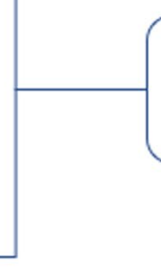

- Access to 'smart capital'

- Access to 'commercialisation competence?

- Access to 'growth competence'

- Sectorial competence

- Technological competence

- Reputation of investor

- Need for legitimacy
Access to

networks

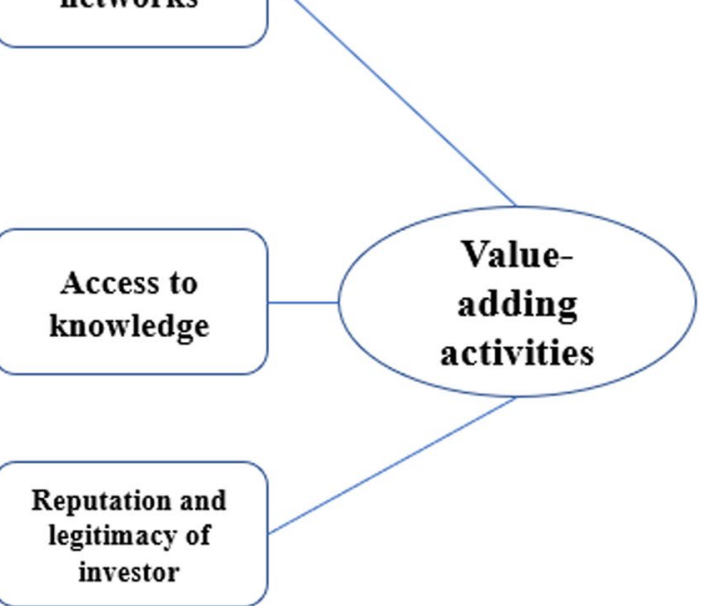

Fig. 4 The construct of value-adding activities

\section{Cultural Aspects Mitigating or Promoting Entrepreneurial Growth}

The construct of cultural issues comprises a set of issues that arise from the lack of a commercial or industrial tradition and an inherent focus on employment and social regional importance over capital gains. The common denominator is that these issues mitigate access to private funding. Although more challenging to conceptualise, the informants presented numerous statements about the cultural conditions, as seen in Table A3 in supplementary file (Fig. 5).

Research on this topic seems to be less clear-cut. Most of the rural actors report on issues concerning sharing control over the company. Such control issues have been associated with growth-oriented entrepreneurship (see e.g. Hansemark, 1998), but the literature has not focused on differences between rural and urban areas. Therefore, rural areas are believed to be more prone to employment-oriented entrepreneurship due to a lack of stimulating cultural, traditional and knowledge-related support, which often arises by agglomeration. The quote of the rural investor illustrates the problem in how investors who offer qualified governance following their investments may be turned away based on a culturebased objection to sharing control with outsiders.

\section{Agglomeration Effects}

The next determinant to capital access is agglomeration effects. Agglomeration is similar to the concept of synergy between firms in corporate finance when sectors and industries achieve benefits of economies of scale. Agglomeration has received much attention in the literature on economic geography and entrepreneurship as a way of explaining economic growth (Acs \& Varga, 2005; Duranton \& Puga, 2004). This determinant is split into two measures. The first measure is related to market and population size and is a well-known determinant (Fig. 6).

Agglomeration effects lie at the core of research on regional development, and the data do not let us omit the topic. These codes are split into two measures: market and population size within reach of the firm (as a rural issue) and the business sector diversity of the region. The representative data can be found in Table A4 in supplementary file.

On an aggregated level, business sector diversity is perhaps a less-discussed facet of agglomeration. As an industrially and demographically spread-out country, Norway is characterised by several rural industrial towns and regions. However, based on the interviews, a large industrial presence does not necessarily improve the conditions for technologically unrelated high-growth start-ups as much as one may like to imagine. Another consequence of agglomeration is that investors in urban areas invest more than their rural counterparts (Avdeitchikova, 2008), and most investors choose to invest in proximal firms. When investing outside their home area, investors prefer co-investment (Mason, 2007; Sørheim, 2006). It follows that if the critical mass of investors or scope of the ecosystem is insufficient, the need 


Codes and terms Measures Aggregated construct

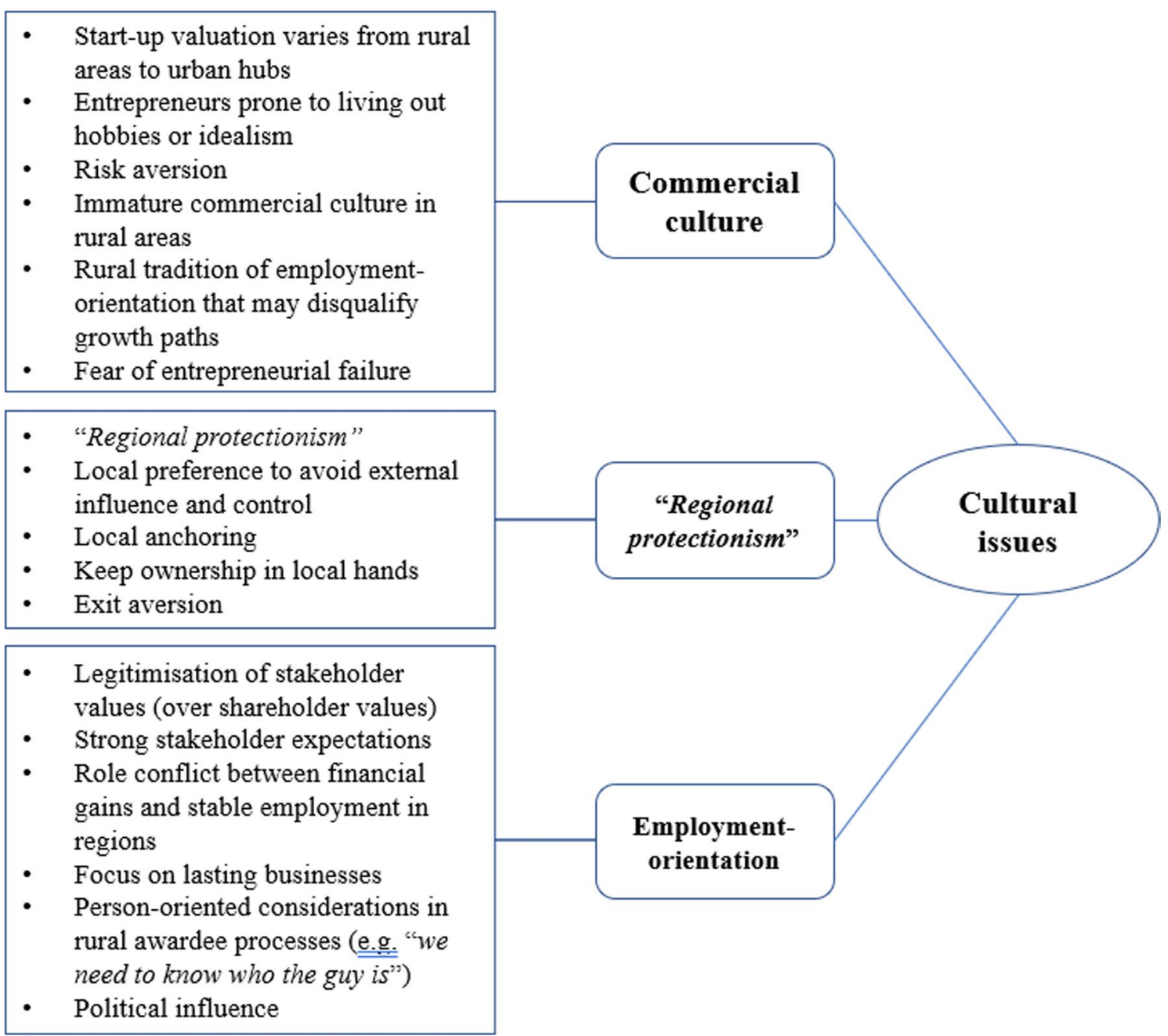

Fig. 5 The construct of cultural issues

for co-investment to overcome asymmetric information and reduce risk increases the disparity of rural locations.

\section{Operating Within Regulatory and Macro-Economic Boundaries}

One cannot omit the role of macro-events and regulations when examining access to finance. The importance of regulations is well recognised in the literature (see e.g. GEM, 2016, 2018). Additionally, the informants frequently referred to regulatory issues that are necessary to include, as evident in Table A5 in supplementary file (Fig. 7).

Most notably, for the past 15 years, the dot-com collapse and the lucrative and less risky real estate market have been believed to limit the availability of start-up capital. Informants claimed that many technology investors who suffered from the dot-com collapse grew vary and became sceptical about fast-growing high-tech businesses. Such an event takes time to recover from. The effects of crises have been relatively thoroughly researched, and these findings are in line with studies on access to finance during crises or sovereign stress (Casey \& O'Toole, 2014; Green, 2004; Lee et al., 2015; Valliere \& Peterson, 2004). However, a novel reflection regards the long-term effects of such crises. As the quotes suggest, the aftermath of such events may last for more than a decade. Therefore, the research topic of access to financial and human capital is complicated. In this specific context, the real estate market underwent substantial and less risky growth and thus became seen as a safer investment. To make this issue transferable to other contexts, the existence of safer sectors with traditionally higher yields has been a hindrance to attracting investments to unrelated and uncertain technologies. 


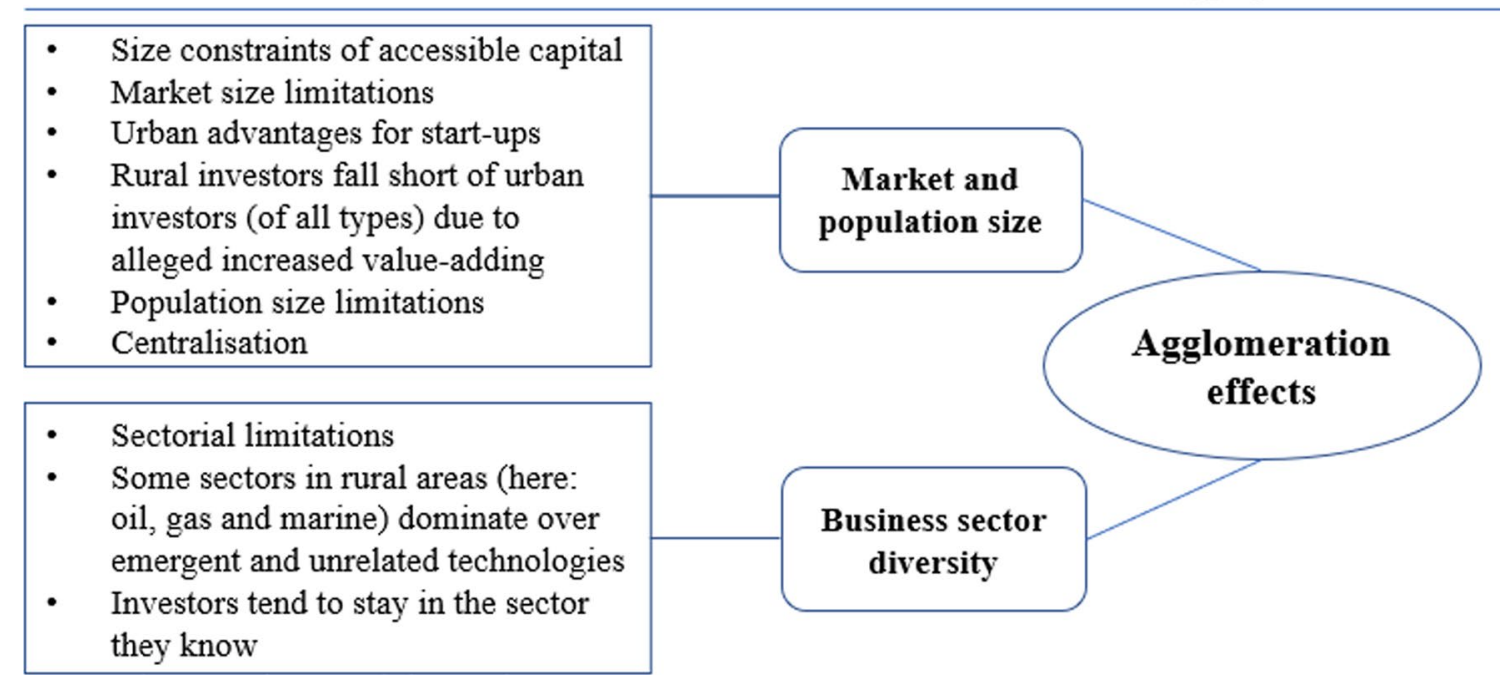

Fig. 6 The construct of agglomeration effects

Regulatory barriers can be negatively associated with entrepreneurship (see e.g. Klapper et al., 2006). During the interviews, three different contextual examples were frequently mentioned: individual tax incentives for start-up investments, options schemes for reducing the threshold for engaging in value-added activities (postponing the taxation of stock compensation in liquidity-constrained start-ups otherwise unable to pay salaries), and banks' ability to compete in the alternative finance market. As laws vary across countries, these context-specific issues were aggregated using regulations as a common label.

\section{The Mechanisms of a Financial Ecosystem}

When listening to the informants' visions for improving entrepreneurial rates, growth and technological progression, the recurring topic was a system where critical resources with minimal friction were made available to viable business concepts. This issue is related to a well-known debate on financial gaps (Murray, 1999), but includes the related resources elaborated in this study. As public support agencies are not expected to bear too much of the responsibility for business and regional development (also referred to as dependent development (Amin, 1999)), the informants drew a picture of a universal self-sustaining business system centred around accessible finance and value-added activities. The model was therefore labelled the Financial Entrepreneurial Ecosystem. This system manifests itself when highlighting how the conceptual elements in the previous sections interrelate.

Juxtaposing the relevant terms and expressions, a pattern is seen in which previous entrepreneurs play an important role in facilitating further growth from the bottom up. This stands in opposition to cluster policy and (regional) innovation systems where the government and public support agencies are the architects from the top-down (Spigel \& Harrison, 2018) (Fig. 8).

The goals of the measures of ecosystem recycling and degree of self-sustainability are twofold. The first aim was to capture the internal dynamics in which the ecosystem's core members use their internally acquired finance and valueadding resources from "The Role of Value-Adding Activities" to spark more business activity in their proximity. As the highlighted quotes will indicate, this is a characteristic that is crucial and distinct to entrepreneurial ecosystems. The second aim was to capture how members of an ecosystem will harvest the system's configurations to purposefully attract further external finance and value-adding activities. When addressing information asymmetry with a potential investor, the firm can play on the ecosystem's risk-dampening benefits to increase the quality of signalling. These two activities reinforce each other and in sum define the degree of self-sustainability and robustness of a financial entrepreneurial ecosystem. Table A6 shows some of the representative data behind the two measures. Many of the quotes may fit in both categories, as seen by the representative data in Table A6 in supplementary file.

The reader might notice that the output differs from the case description. The initial engagement in the project was to try to frame a national configuration of a financial ecosystem, while the output of the analysis describes the financial configurations of a business ecosystem in general. Such proposed systems, however, can vary in shape from small, rural and isolated to massive and urban. They can also transcend geography and be dispersed. 
- Dot-com bubble (around 2001)

- IT-bubble (around 2001)

- Oil bubble (around 2014)

- Oil price decrease (around 2014)

- Property investments take attention from private and unnoted businesses due to higher historic and expected future yields

- Offshore and marine sectors take attention from new and emergent investor cases due to higher historic and future expected yields

- Beneficial tax schemes for startups

- Beneficial tax schemes for investors

- Beneficial options schemes for start-up/investor relations

- Bureaucracy as bottleneck

- Finance Authority limits maneuverability for start-up access to bank loans

- Credit authority limitations

- Regulatory complexity and inherent reputational risk of alternative funding

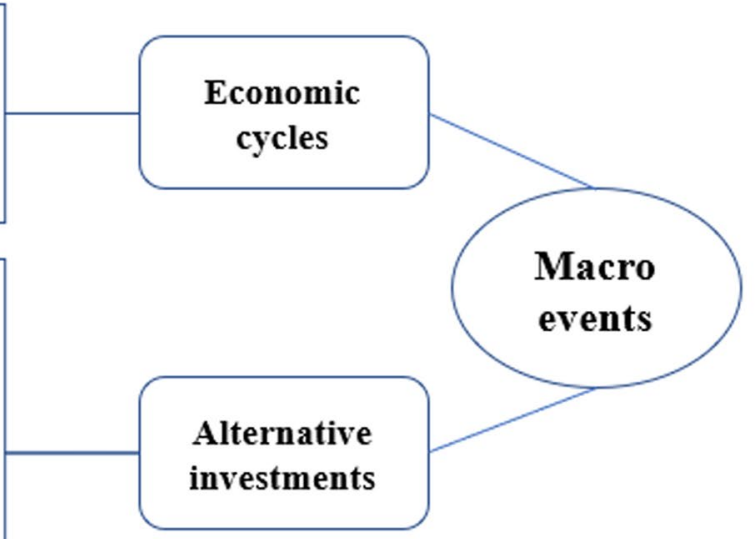

Alternative

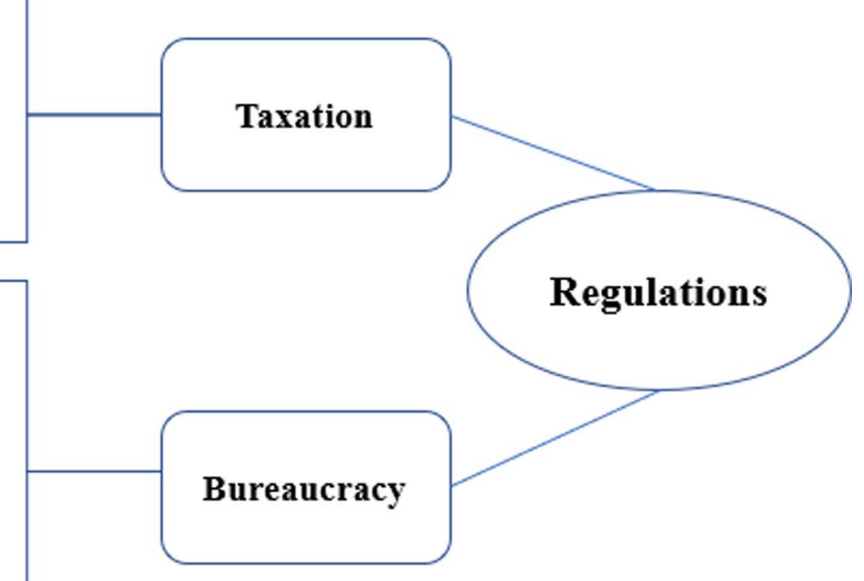

Fig. 7 The aggregated construct of macro-events and regulations

- "Pockets of innovation" and "Rural islands"

- Dynamics of an ecosystem

- Proximal spin-offs

- Feedback loops from serial founders

- Feedback cycles of investments and knowledge

- Financial ecosystem

- Entrepreneurial ecosystem

- "The Norwegian ecosystem is fast-growing"

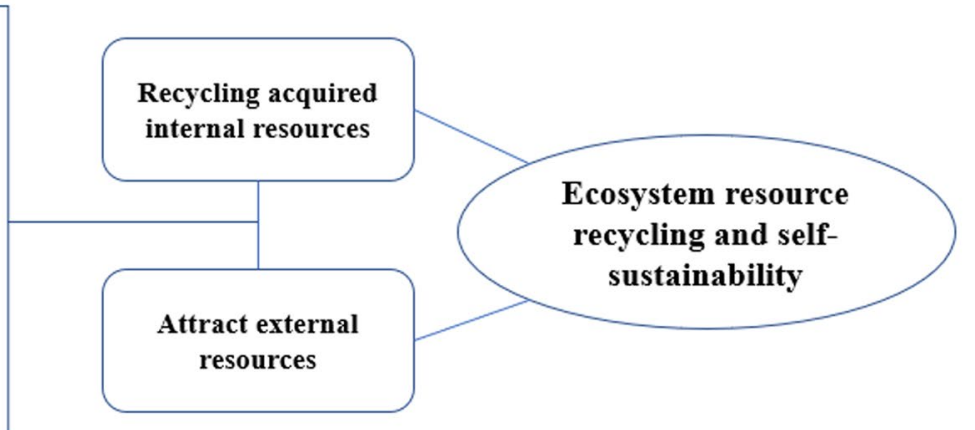

Fig. 8 The construct of ecosystem resource recycling and self-sustainability 
Fig. 9 Conceptual linkages in the financial entrepreneurial ecosystem

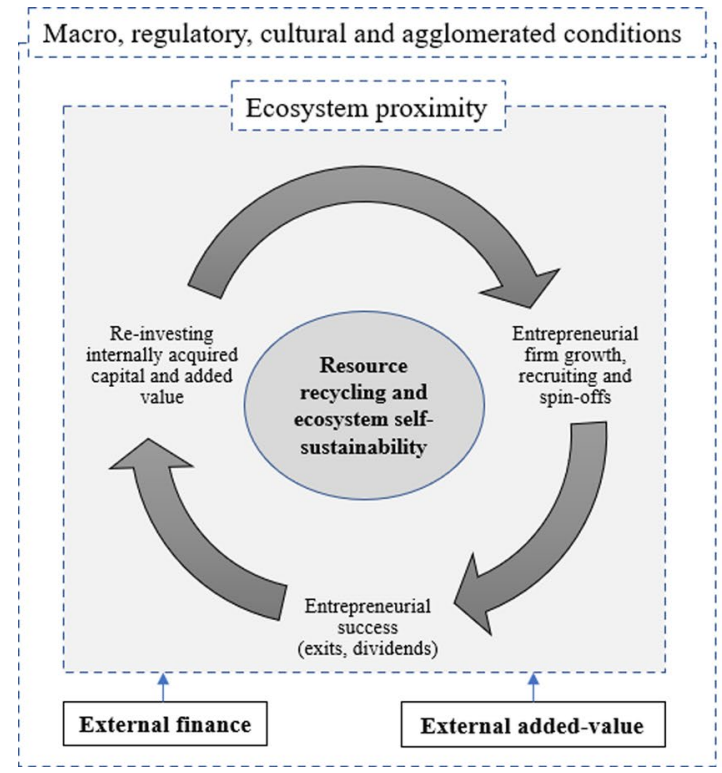

Assumptions:

1) Ecosystem sustainability increases the quality of signaling towards external financiers.

2) Ecosystem participation provides legitimacy, reputation and alleged access to entrepreneurial resources. It thus reduces the degree of information asymmetry between the ecosystem and external actors.

\section{How These Elements Interrelate in a Financial Entrepreneurial Ecosystem}

The main determinants to financial access in the Norwegian context have now been mapped, and the notion of a financial ecosystem and the characteristics of such a system have been examined. The next step is to conceptualise how the determinants interrelate systematically. Figure 9 provides a summary of the conceptual elements and their interrelations.

In the case of the ecosystem of Startuplab in Oslo, the informant stated that the Founder's fund could make investments at an earlier stage, which can be explained by lower levels of information asymmetry facilitated by the ecosystem. Such investments, together with the ecosystem's legitimising reputation as a source of added value, further dampen the risk for external investors. The result is more fruitful fundraising and better chances of firm survival and performance.

The ecosystem as a whole will be influenced by the overall macro, regulatory, cultural and agglomerated conditions of their context. The financial ecosystem process is believed to look alike in rural subsidy-based and urban equity-based economies, albeit with different degrees of robustness determined by external factors.

\section{Discussion}

The Financial Entrepreneurial Ecosystem framework links the EE perspective (Isenberg, 2010, 2011) in regional development with agency issues such as information asymmetry and signalling theory from strategic management. Several of the external and conditional data-derived factors would seem to overlap with Isenberg's six domains. However, the lack of equivalence between the frameworks might be a result of contextual differences, the use of social constructs derived from researchers' interpretations of qualitative data, or differences in what they set out to measure in the first place. Consequently, the model based on this qualitative inquiry is not expected to be directly equivalent to the EE framework (Table 2).
Table 2 Comparison with the six domains of the entrepreneurial ecosystem

\begin{tabular}{ll}
\hline $\begin{array}{l}\text { The determinants and conditional factors of the } \\
\text { financial entrepreneurial ecosystem }\end{array}$ & $\begin{array}{l}\text { Domains of the entrepreneurial eco- } \\
\text { system framework (Isenberg, 2010, } \\
2011)\end{array}$ \\
\hline Culture & $\begin{array}{l}\text { Similar to Culture } \\
\text { No direct equivalent }\end{array}$ \\
Agglomeration effects & No direct equivalent \\
No direct equivalent & Policy \\
Regulations & Similar to Supports \\
Financial availability & Similar to Finance \\
Value-adding activities & Similar to Human Capital \\
\hline
\end{tabular}


The EE framework examines the conditions of entrepreneurship in a more exhaustive matter, so this comparison is for benchmark purposes only. The measures are selected due to their specific roles in this context. However, an interesting missing element is the role of policy. As Spigel (2018) and Spigel and Harrison (2018) argue, an ecosystem is a bottom-up process that is centred on the entrepreneur. This study assumes the same, that is, that ecosystems are the result of entrepreneurial and financial actors reacting to opportunities and therefore cannot be created through policy. To recall a quote from an urban investor, 'You cannot have a self-sufficient ecosystem-based only on governmental subsidies. A self-sustaining ecosystem has a strong interplay between private businesses'. Governmental actors, on the other hand, may catalyse the development and unlock more finance and value-added activities by emphasising matching capital programs similar to successful cases (see e.g. Cumming et al., 2014; Guerini \& Quas, 2016; Leleux \& Surlemont, 2003). Whether Norway is such a case has not been examined, but the following quote from an urban seed fund manager may indicate a role of the public sector in ecosystem emergence:

[...] Norway is the fastest-growing [eco]system, and I believe something happened last year. Altogether, a considerable amount was invested [through governmental pre-seed funds], and only in the early phase. So much finance for start-ups has not been available before.

The main difference between the EE framework and other systemic frameworks seems to be that the EE framework builds on some sort of entrepreneurial success. This means that fundamental conditions such as investments and valueadding activities are made proximally available, which is different from clusters and IS, as the latter focus more on general knowledge sharing. The practical implication for policy is that more attention needs to be moved from creating innovative clusters to acknowledging that catalysing and connecting existing ecosystems may be more effective. As one informant stated, there can be ecosystems within an ecosystem, which should make vertical connectedness from national systems to regional systems a policy agenda. As Stam (2015) noted, instead of quantifying firm formation as the output of the (innovation) system, policy should be concerned with how to promote the recycling of resources in ecosystems. The ecosystem perspective implies that policymakers acknowledge that viable business creation is not something that could and should take place anywhere but instead focuses on places where some sort of entrepreneurial success is emerging.

Further comparing the model to other similar frameworks, internal financial ecosystem mechanisms increase the signalling quality for sources of external finance and lower the degree of information asymmetry. A nascent start-up may infuse into the ecosystem and borrow its legitimacy, reputation and track record to increase the amount of external finance and value-adding activities. Taken together, these mechanisms lead to a self-sustaining and self-strengthening system of entrepreneurship that is aligned with the informants' alleged goals and policy visions. The concept of a financial entrepreneurial ecosystem will therefore be defined as (1) a self-sustaining system of a sufficient number of startups, intermediaries and capital providers with (2) sufficient competency and financial resources that are (3) effectively acquired, distributed and shared among viable and eligible members through effective feedback loops within a reasonable time when needed.

This study did not focus on quantitative performance measures, as all common performance indicators are facets of an efficient financial ecosystem. Whether one talks about firm survival, growth in sales/turnover/profit/employees, exits, dividends, aggregated tax income or regional development, establishing self-sustainable ecosystems may promote most if not all. On the downside, however, such a system seems to require a critical mass of entrepreneurs or initial performance, and the government may not trigger the creation of ecosystem and business activity in deprived areas in the same way as the abovementioned theories suggest.

Finally, even though the context of this study is Norway, the aim has been to look at mechanisms and theoretical implications that relate to networks of businesses in general. A consequence of ecosystem interactions between key actors, nascent or new firms, and support agencies is the increased competitiveness of the group. Resources critical to growth (previously referred to primarily knowledge, finance, and governance) can be more effectively distributed when the ecosystem is highly interdependent. For instance, all of these three ecosystem effects can alleviate misallocation of finance and production inefficiency (Arulraj \& Annamalai, 2020).

\section{Conclusion}

Research on entrepreneurial ecosystems continues to gain momentum, and this study examined the financial configurations of such systems. Although finance is a critical ingredient for entrepreneurship, no studies seem to have examined how it is distributed and recycled in entrepreneurial ecosystems.

As previous theories do not suffice to answer questions about financial interrelations in ecosystems, the selected method was a multiple-case design of the financial ecosystem in two Norwegian rural and urban contexts. Building on different theoretical insights from existing ecosystem frameworks and agency issues in management, the Financial 
Entrepreneurial Ecosystem framework was elaborated to explain how financial sources and closely related valueadding activities are (1) internally recycled in ecosystems and subsequently (2) add risk dampening, legitimacy and networks to further attract external non-ecosystem resources. Together, these mechanisms enhance the ecosystem's robustness and degree of self-sustainability.

The second contribution is how the framework explains such interrelations in small systems based on one single successful entrepreneur to large industrial systems across regions and national configurations. It further underlines how rural actors may overcome barriers determined by their locality to attract necessary resources and thus links the research fields of regional development and entrepreneurial finance.

The practical consequence of the study is a warning to policymakers and public support agencies against believing such ecosystems can be created externally. Instead, they should focus more on how they can catalyse ecosystem emergence through their ability as public actors to dampen the risk for private involvement. Investing in early-phase start-ups is still a risky affair, but policies should exploit ecosystems' abilities to contribute internal smart capital and legitimacy in order to incentivise more investors to overcome sectorial and technological barriers. Such policies will differ in character, as they will be less quantitatively measured by the number of grants awarded to ideas and instead more qualitatively focused on long-term interrelations between private businesses and nascent or mature ecosystems. This means a revision of current entrepreneurship policies. This paper concludes that such policies should aim to enhance entrepreneurial ecosystems' recycling dynamics and vitality through regulatory and conditional stimuli. Therefore, this study is in line with the alleged transition of focus from quantitative entrepreneurship to qualitative entrepreneurship (Stam, 2015).

\section{Key Questions Reflecting Applicability in Real Life}

1. What is the role of finance in entrepreneurial ecosystems?

2. What is a financial entrepreneurial ecosystem and how can it be used by practitioners?

3. What do we mean by "recycling of entrepreneurial finance", and why does it matter for policy?

4. What can a practitioner, support agency or policymaker do to enhance the entrepreneurial activity without increased resource allocation?

Supplementary Information The online version contains supplementary material available at https://doi.org/10.1007/s42943-022-00050-2.

Acknowledgements I would like to thank the editor and two anonymous reviewers at International Journal of Global Business and
Competitiveness for their effective and constructive feedback. I also like to thank Rotem Shneor for valuable help in the development of the paper.

Funding Open access funding provided by Western Norway University Of Applied Sciences. Not applicable.

Data Availability Statement The data that support the findings of this study are available from the corresponding author upon reasonable request.

\section{Declarations}

Conflict of Interest The author confirms no conflict of interests.

Ethics Approval The data collection procedures followed the requirements of Norwegian Centre for Research Data (https://www.nsd.no/).

Open Access This article is licensed under a Creative Commons Attribution 4.0 International License, which permits use, sharing, adaptation, distribution and reproduction in any medium or format, as long as you give appropriate credit to the original author(s) and the source, provide a link to the Creative Commons licence, and indicate if changes were made. The images or other third party material in this article are included in the article's Creative Commons licence, unless indicated otherwise in a credit line to the material. If material is not included in the article's Creative Commons licence and your intended use is not permitted by statutory regulation or exceeds the permitted use, you will need to obtain permission directly from the copyright holder. To view a copy of this licence, visit http://creativecommons.org/licenses/by/4.0/.

\section{References}

Acs, Z. J., Stam, E., Audretsch, D. B., \& O'Connor, A. (2017). The lineages of the entrepreneurial ecosystem approach. Small Business Economics, 49(1), 1-10.

Acs, Z. J., \& Varga, A. (2005). Entrepreneurship, agglomeration and technological change. Small Business Economics, 24(3), 323-334.

Alperovych, Y., Hübner, G., \& Lobet, F. (2015). How does governmental versus private venture capital backing affect a firm's efficiency? Evidence from Belgium. Journal of Business Venturing, 30(4), 508-525.

Amin, A. (1999). An institutionalist perspective on regional economic development. International Journal of Urban and Regional Research, 23(2), 365-378.

Ang, J. S. (1992). On the theory of finance for privately held firms. The Journal of Entrepreneurial Finance, 1(3), 185-203.

Arulraj, D. J., \& Annamalai, T. R. (2020). Firms' financing choices and firm productivity: Evidence from an emerging economy. International Journal of Global Business and Competitiveness, $15,35-48$.

Asheim, B. R. T. (1996). Industrial districts as 'learning regions': a condition for prosperity. European planning studies, 4(4), 379-400.

Avdeitchikova, S. (2008). On the structure of the informal venture capital market in Sweden: Developing investment roles. Venture Capital, 10(1), 55-85. https://doi.org/10.1080/13691060701605504

Bastesen, J., \& Vatne, E. (2014). Rapid-growth firms: exploring the role and location of entrepreneurial ventures. In Agglomeration, clusters and entrepreneurship: Studies in regional economic development, pp. 159-198. 
Bornefalk, A. (2014). Kapital på krita?: en ESO-rapport om företagandets finansiering. Stockholm: Finansdepartementet, Regeringskansliet.

Boschma, R. (2005). Proximity and innovation: A critical assessment. Regional Studies, 39(1), 61-74.

Burt, R. S. (2004). Structural holes and good ideas. American Journal of Sociology, 110(2), 349-399.

Casey, E., \& O'Toole, C. M. (2014). Bank lending constraints, trade credit and alternative financing during the financial crisis: Evidence from European SMEs. Journal of Corporate Finance, 27, 173-193. https://doi.org/10.1016/j.jcorpfin.2014.05.001

Cassar, G. (2004). The financing of business start-ups. Journal of Business Venturing, 19(2), 261-283.

Cooke, P., Uranga, M. G., \& Etxebarria, G. (1997). Regional innovation systems: Institutional and organisational dimensions. Research Policy, 26(4-5), 475-491.

Cumming, D., Grilli, L., \& Murtinu, S. (2014). Governmental and independent venture capital investments in Europe: A firm-level performance analysis. Journal of Corporate Finance., 42, 439-459.

Denis, D. J. (2004). Entrepreneurial finance: An overview of the issues and evidence. Journal of Corporate Finance, 10(2), 301-326.

Duranton, G., \& Puga, D. (2004). Micro-foundations of urban agglomeration economies. Handbook of Regional and Urban Economics, 4, 2063-2117.

Eisenhardt, K. M. (1989a). Agency theory: An assessment and review. Academy of Management Review, 14(1), 57-74.

Eisenhardt, K. M. (1989b). Building theories from case study research. Academy of Management Review, 14(4), 532-550.

Etzkowitz, H. (2008). The triple helix: University-industry-government innovation in action. Routledge.

Fitjar, R., \& Rodríguez-Pose, A. (2019). Where cities fail to triumph: The impact of urban location and local collaboration on innovation in Norway. Journal of Regional Science. https://doi.org/10. 1111 /jors. 12461

Gehman, J., Glaser, V. L., Eisenhardt, K. M., Gioia, D., Langley, A., \& Corley, K. G. (2018). Finding theory-method fit: A comparison of three qualitative approaches to theory building. Journal of Management Inquiry, 27(3), 284-300. https://doi.org/10.1177/ 1056492617706029

GEM. (2016). GEM-entrepreneurial finance special report 2015-2016.

GEM. (2018). GEM 2017/2018 global report.

Gjelsvik, M., \& Trippl, M. (2018). Financial organizations: An overlooked element in regional innovation systems. New avenues for regional innovation systems-theoretical advances, empirical cases and policy lessons (pp. 107-125). Cham: Springer.

Green, J. (2004). Venture capital at a new crossroads: Lessons from the Bubble. Journal of Management Development, 23(10), 972-976.

Guerini, M., \& Quas, A. (2016). Governmental venture capital in Europe: Screening and certification. Journal of Business Venturing, 31(2), 175-195. https://doi.org/10.1016/j.jbusvent.2015.10. 001

Hansemark, O. C. (1998). The effects of an entrepreneurship programme on need for achievement and locus of control of reinforcement. International Journal of Entrepreneurial Behavior \& Research, 4(1), 28-50. https://doi.org/10.1108/1355255981 0203957

Hsu, D. H. (2004). What do entrepreneurs pay for venture capital affiliation? The Journal of Finance, 59(4), 1805-1844. https://doi.org/ 10.1111/j.1540-6261.2004.00680.x

Isenberg, D. (2011). The entrepreneurship ecosystem strategy as a new paradigm for economic policy: Principles for cultivating entrepreneurship. Presentation at the Institute of International and European Affairs, 1(781), 1-13. Dublin.
Isenberg, D. (2010). How to start an entrepreneurial revolution. Harvard Business Review, 88(6), 40-50.

Jensen, M. C., \& Meckling, W. H. (1976). Theory of the firm: Managerial behavior, agency costs and ownership structure. Journal of Financial Economics, 3(4), 305-360. https://doi.org/10.1016/ 0304-405X(76)90026-X

Kapitaltilgangsutvalget. (2018). Kapital i omstillingens tid - Naringslivets tilgang til kapital (NOU 2018:5, Issue. https://www.regje ringen.no/no/dokumenter/nou-2018-5/id2590735/

Kerr, W. R., \& Nanda, R. (2015). Financing innovation. Annual Review of Financial Economics, 7, 445-462.

Klapper, L., Laeven, L., \& Rajan, R. (2006). Entry regulation as a barrier to entrepreneurship. Journal of Financial Economics, 82(3), 591-629.

Kvale, S. (2008). Doing interviews. New York: Sage.

Landström, H. (2004). Pioneers in entrepreneurship research. In Crossroads of entrepreneurship (pp. 13-31).

Landström, H. (2017). Advanced introduction to entrepreneurial finance. Cheltenham: Edward Elgar Publishing.

Lee, N., Sameen, H., \& Cowling, M. (2015). Access to finance for innovative SMEs since the financial crisis. Research Policy, 44(2), 370-380. https://doi.org/10.1016/j.respol.2014.09.008

Leleux, B., \& Surlemont, B. (2003). Public versus private venture capital: Seeding or crowding out? A pan-European analysis. Journal of Business Venturing, 18(1), 81-104.

Lerner, J., Schoar, A., Sokolinski, S., \& Wilson, K. (2018). The globalization of angel investments: Evidence across countries. Journal of Financial Economics, 127(1), 1-20.

Liguori, E., Bendickson, J., Solomon, S., \& McDowell, W. C. (2019). Development of a multi-dimensional measure for assessing entrepreneurial ecosystems. Entrepreneurship \& Regional Development, 31(1-2), 7-21.

Malecki, E. J. (2018). Entrepreneurship and entrepreneurial ecosystems. Geography Compass, 12(3), e12359. https://doi.org/10. $1111 /$ gec3.12359

Marshall, A. (1919). Industry and trade: A study of industrial technique and business organization; and of their influences on the conditions of various classes and nations. Basingstoke: Macmillan.

Mason, C. (2007). Venture capital: A geographical perspective. Handbook of research on venture capital (pp. 86-112). Cheltenham: Edward Elgar.

Miles, M. B., \& Huberman, A. M. (1994). Qualitative data analysis. An expanded sourcebook. New York: Sage.

Momaya, K. S. (2019). The past and the future of competitiveness research: A review in an emerging context of innovation and EMNEs. International Journal of Global Business and Competitiveness, 14, 1-10. https://doi.org/10.1007/s42943-019-00002-3.

Murray, G. (1999). Early-stage venture capital funds, scale economies and public support. Venture Capital: An International Journal of Entrepreneurial Finance, 1(4), 351-384.

Myers, S. C. (1984). The capital structure puzzle. The Journal of Finance, 39(3), 574-592.

Nathan, M. (2019). Does light touch cluster policy? Work Evaluating the tech city programme. Research Policy. https://doi.org/10. 1016/j.respol.2020.104138.

Ostrom, E. (2010). Beyond markets and states: Polycentric governance of complex economic systems. American Economic Review, 100(3), 641-672.

Ozcan, P., \& Eisenhardt, K. M. (2009). Origin of alliance portfolios: Entrepreneurs, network strategies, and firm performance. Academy of Management Journal, 52(2), 246-279.

Peneder, M. (2010). The impact of venture capital on innovation behaviour and firm growth. Venture Capital, 12(2), 83-107. https://doi. org/10.1080/13691061003643250 
Politis, D. (2008). Business angels and value added: What do we know and where do we go? Venture Capital, 10(2), 127-147. https://doi. org/10.1080/13691060801946147

Porter, M. E. (1998). Clusters and the new economics of competition (Vol. 76, No. 6, pp. 77-90). Boston: Harvard Business Review.

Pratt, M. G., Kaplan, S., \& Whittington, R. (2019). Editorial essay: The tumult over transparency: Decoupling transparency from replication in establishing trustworthy qualitative research. Administrative Science Quarterly. https://doi.org/10.1177/0001839219 887663

Radinger-Peer, V., Sedlacek, S., \& Goldstein, H. (2018). The pathdependent evolution of the entrepreneurial ecosystem (EE)dynamics and region-specific assets of the case of Vienna (Austria). European Planning Studies, 26(8), 1499-1518.

Reve, T. (2017). MIT reap-Regional entrepreneurship acceleration programme-South West Norway. https://www.bi.no/globalasse ts/forskning/forskningskommunikasjon/rapporter/mit-reap-slutt rapport-2017.pdf

Sorenson, O., \& Stuart, T. E. (2001). Syndication networks and the spatial distribution of venture capital investments. American Journal of Sociology, 106(6), 1546-1588.

Sørheim, R. (2006). Finansiering av vekstbedrifter. I Jensen JI, Kolvereid L \& Erikson T (red),(2006). Perspektiver på entrepren $\phi r s k a p$. Oslo: Høyskoleforlaget, 173-187.

Spence, M. (1978). Job market signaling. In Uncertainty in economics (pp. 281-306). Amsterdam: Academic Press. Elsevier.

Spigel, B., \& Harrison, R. (2018). Toward a process theory of entrepreneurial ecosystems. Strategic Entrepreneurship Journal, 12(1), 151-168. https://doi.org/10.1002/sej.1268

Spigel, B. (2017). The relational organization of entrepreneurial ecosystems. Entrepreneurship Theory and Practice, 41(1), 49-72.

Spigel, B. (2018). Envisioning a new research agenda for entrepreneurial ecosystems: Top-down and bottom-up approaches. In Reflections and Extensions on Key Papers of the First Twenty-Five Years of Advances. Emerald Publishing Limited.

Spilling, O. R. (1996). The entrepreneurial system: On entrepreneurship in the context of a mega-event. Journal of Business Research, 36(1), 91-103.

Stam, E. \& Spigel, B. (2016). Entrepreneurial ecosystems. USE discussion paper series, $16(13)$.

Stam, E. (2018). Measuring entrepreneurial ecosystems. In A. O'Connor, E. Stam, F. Sussan, \& D. Audretsch (Eds.), entrepreneurial ecosystems (pp. 173-197). Cham: Springer.
Stam, E. (2015). Entrepreneurial ecosystems and regional policy: A sympathetic critique. European Planning Studies, 23(9), $1759-1769$.

Theodoraki, C., \& Catanzaro, A. (2021). Widening the borders of entrepreneurial ecosystem through the international lens. The Journal of Technology Transfer. https://doi.org/10.1007/ s10961-021-09852-7

Valliere, D., \& Peterson, R. (2004). Inflating the bubble: Examining dot-com investor behaviour. Venture Capital, 6(1), 1-22. https:// doi.org/10.1080/1369106032000152452

Van de Ven, H. (1993). The development of an infrastructure for entrepreneurship. Journal of Business Venturing, 8(3), 211-230.

Vedula, S., \& Kim, P. H. (2019). Gimme shelter or fade away: The impact of regional entrepreneurial ecosystem quality on venture survival. Industrial and Corporate Change, 28(4), 827-854.

Wurth, B., Stam, E., \& Spigel, B. (2021). Toward an entrepreneurial ecosystem research program. Entrepreneurship Theory and Practice. https://doi.org/10.1177/1042258721998948

Yin, R. K. (2013). Case study research: Design and methods. New York: Sage.

Zacharakis, A. L., Shepherd, D. A., \& Coombs, J. E. (2003). The development of venture-capital-backed internet companies: An ecosystem perspective. Journal of Business Venturing, 18(2), 217-231.

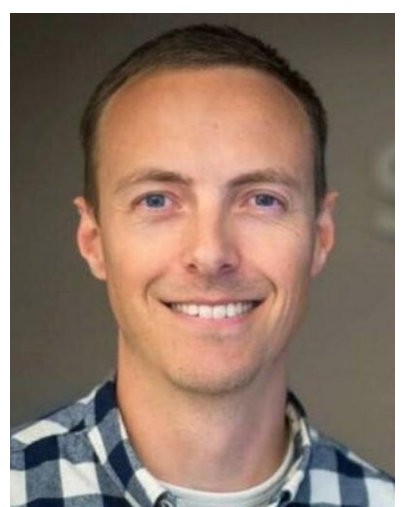

Tore Frimanslund is employed at the Western Norway University of Applied Sciences. He finished his $\mathrm{PhD}$ titled "Regional access to entrepreneurial finance and entrepreneurial finance ecosystems - Determinants of and barriers to ecosystem finance" in January 2022. His doctoral work was conducted at the University of Agder, Norway. His academic interests are entrepreneurship, finance, entrepreneurial ecosystems and regional development. 